Pak. j. sci. ind. res. Ser. A: phys. sci. 201659 (1) 23-29

\title{
Synthesis and Application of Highly Active Dithiooxamide Functionalised Multi-Walled Carbon Nanotubes Toward Mercury Removal from Aqueous Solution
}

\author{
Mirabi Alia*, Shokuhi Rad Ali ${ }^{\mathrm{b}}$, Siadati Seyyed Amir ${ }^{\mathrm{a}}$ and Alavi Tabari Seyyed Ali ${ }^{\mathrm{a}}$ \\ ${ }^{a}$ Department of Chemistry, Qaemshahr Branch, Islamic Azad University, Qaemshahr, Iran \\ ${ }^{b}$ Department of Chemical Engineering, Qaemshahr Branch, Islamic Azad University, Qaemshahr, Iran
}

(received January 20, 2015; revised July 31, 2015; accepted August 3, 2015)

\begin{abstract}
Highly sensitive and accurate method has been applied for removal of toxic mercury(II) ions in aqueous solution, using synthesised nanosorbent. Determination of mercury(II) was carried out by flame atomic absorption spectrometer. A nanosorbent multi-walled carbon nanotubes (MWCNT) was synthesised by the reaction of dithiooxamide with functionalised multi-walled carbon nanotubes. Initially, the surface of the multi-walled carbon nanotubes was oxidised by a mixture of nitric and sulphuric acids and then was functionalised using thionyl chloride. The ligand has been attached to the multi-walled carbon nanotubes in somewhat shorter time and lower temperature than previous reported methods. The sorbent was characterised by Fourier transmission infrared and scanning electron microscopy. In this research study, the effect of different parameters in removal of mercury(II) ions by nanosorbent, such as $\mathrm{pH}$, amount of nanosorbent, time and concentration of $\mathrm{Hg}(\mathrm{II})$, was investigated. Experiments show that the new MWCNT with loading amount of $1.02 \mathrm{mmol} / \mathrm{g}$ is a powerful sorbent for removing the $\mathrm{Hg}(\mathrm{II})$ ions from water.
\end{abstract}

Keywords: carbon nanotubes, mercury removal, aqueous solution, dithiooxamide

\section{Introduction}

Mercury is considered as a highly toxic element because of its accumulative and persistent character in the environment (Wu et al., 2007). It is one of the famous agents in wide range of human disorders especially in breath cancer (Mishra et al., 2005). Although mercury is not an abundant chemical element in nature, it has become dangerously widespread as a result of many industrial and agricultural applications and its threat is rising day-by-day. The major sources of mercury pollution to the environment are waste effluents from the metal plating industry, mining operations, fertilizer industry, tanneries, and textile industry (Farajim et al., 2010; Sukocheva et al., 2005). The major effects of mercury poisoning are neurological and renal disturbances as well as impairment of pulmonary function. Natural inputs of mercury to the environment are related to weathering of mercuriferous areas, the degassing from surface water and from the crust through volcanic eruptions, naturallycaused forest fires, and biogenic emissions of the earth (Jones et al., 2007; Liu et al., 2007; Green-Ruiz, 2006; Manohar et al., 2002; Boening, 2000), therefore, elimination of the $\mathrm{Hg}(\mathrm{II})$ ions from water is essentially required. In this regard, different types of sorbents such as resins, activated chars(Klasson et al., 2010), polymers (Zong

*Author for correspondence; E-mail: mirabi2012@yahoo.com et al., 2001), metal nanooxides, oxidized carbon nanotubes and fibre biosorbents (Johari et al., 2014) were evaluated. Sorbents with high surface area, which can lead to high removal of $\mathrm{Hg}$ (II) ions, are interesting to the researchers. Discovery of multi-walled carbon nanotubes (MWCNT) in 1991 has generated extensive activity in most areas of science and engineering due to molecular electronics, sensoring, nerve cell stimuli, drug delivery, cancer therapy and chemical properties (El-Sheikh et al., 2011). They have become attractive materials for their novel structure characters and high surface area. The unique tubular structure makes CNTs promising absorbent materials, and thus may be used in removal of many pollutants.

In particular, chemical functionalization of carbon nanotubes (CNTs) can modify their physical and chemical properties, leading to the improvement of their performance for specific applications. Thus, the extensive research has been focused on the functionalization of CNTs which can be cited fluorination (Pourrezar et al., 2009), carbene addition (Malic et al., 2010), esterification (Hu et al., 2004) and amidation (Venkatesan et al., 2005).

One method for functionalizing of the carbon nanotubes is its oxidation by a strong and concentrated nitric and sulphuric acids mixture (Kalita et al., 2008; Yu et al., 2008). 
The produced MWCNT-COOH was reacted with thionyl chloride in the presence and absence of dimethylformamide (DMF) (Yu et al., 2008b). Moreover, the MWCNT-COCl reacts with various ligands which mostly take more than $80 \mathrm{~h}$ (Sone and Yagi, 2009; Teixeira et al., 2006; Wang et al., 2006).

In this study, oxidation of MWCNT was performed by a mixture of nitric and sulphuric acids. Thionyl chloride was then used to produce the acid chloride functional group on the CNT. Finally the MWCNT-COCl was reacted with dithiooxamide in shorter time and under lower temperature than previous reported methods (Tahermansouri et al., 2013; Barbara et al., 2011; Yang et al., 2009) and then the dithiooxamide functionalised MWCNT was used as a sorbent to remove the toxic $\mathrm{Hg}$ (II) ions in different aqueous solutions.

\section{Materials and Methods}

Reagents. All chemicals were in analytical grade reagents. All solutions were prepared using double distilled water. A stock standard solution containing $1000 \mathrm{mg} / \mathrm{L}$ of $\mathrm{Hg}$ (II) was prepared via dissolving appropriate amounts of its nitrate salt $\mathrm{Hg}\left(\mathrm{NO}_{3}\right)_{2}$ (obtained from Merck company, Darmstadt, Germany) in distilled water and $0.5 \mathrm{~mL}$ concentrated nitric acid that was purchased from Merck company. The multi-walled carbon nanotubes (MWCNT), thionylchloride, triethanolamine, dimethylformamide (DMF), dithiooxamide (ligand), sulphuric acid, and nitric acid were used without further purification.

Instrumentation. Thermo Scientific (model: M5) flame atomic absorption spectrometer with a mercury hollow cathode lamp as a radiation source, operated at $15 \mathrm{~mA}$ with a monochromator spectral band pass of $1.0 \mathrm{~nm}$ was used for the determination of the exact mercury amount. The wavelength selected for mercury was $253.6 \mathrm{~nm}$. An air-acetylene flame was used for the determination of mercury ions and their flow rates were $10.0 \mathrm{~L} / \mathrm{min}$ and $0.8 \mathrm{~L} / \mathrm{min}$, respectively. Also, this device was equipped with a $50 \mathrm{~mm}$ burner head and deuterium background correction. The $\mathrm{pH}$ was measured using a Metrohm pH meter (model 744) with a combined $\mathrm{pH}$ glass electrode calibrated against two standard buffer solutions ( $\mathrm{pH} 4.0$ and 7.0). Other instruments which have been used were: Fourier transmission infrared spectrophotometer (Shimadzu, model 1280), scanning electron microscope (LEO 440i, leo electron microscopy, Cambridge, England) and UV-Vis spectrophotometer (Jenway model 6505).
Functionalisation of carbon nanotubes sorbent. The MWCNT ( $4.0 \mathrm{~g})$ were added to $30.0 \mathrm{~mL}$ of a mixture of sulphuric acid and nitric acid $(3: 1 \mathrm{v} / \mathrm{v})$, and then the mixture was heated at $80{ }^{\circ} \mathrm{C}$ for $2 \mathrm{~h}$. The resulted MWCNT-COOH was centrifuged at $4000 \mathrm{rpm}$ for 5 min to remove excess acids and then was eluted by distilled water and dried at $80{ }^{\circ} \mathrm{C}$. Dried $3.0 \mathrm{~g}$ of the MWCNT-COOH was dispersed in $15.0 \mathrm{~mL}$ of thionyl chloride and refluxed at $70{ }^{\circ} \mathrm{C}$ for $1 \mathrm{~h}$. After synthesis of MWCNT-COCl it was eluted with anhydrous toluene and then dried in oven at $70^{\circ} \mathrm{C}$ for $48 \mathrm{~h} .3 .0 \mathrm{~g}$ of MWCNT$\mathrm{COCl}$ has been dispersed using ultrasonic in DMF as solvent and $0.5 \mathrm{~g}$ of dithiooxamide and $0.3 \mathrm{~mL}$ of triethanolamine were added to the mixture, subsequently (Scheme 1). The mixture was heated at $80^{\circ} \mathrm{C}$ for $30 \mathrm{~h}$. The synthesised MWCNT-CO-dithiooxamide was separated from the reaction mixture by centrifugation and washed with distilled water.

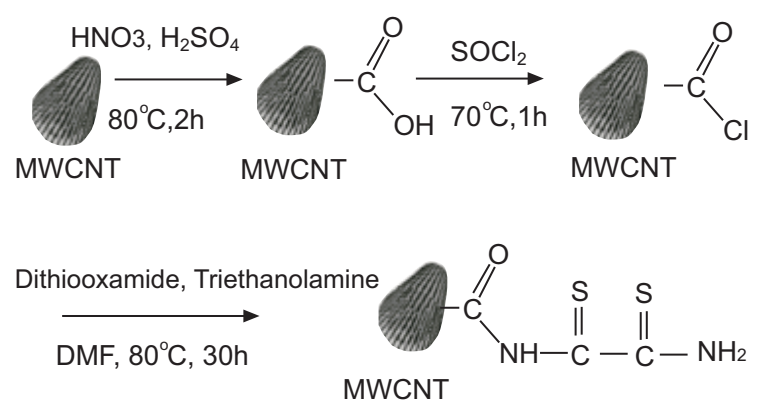

Scheme 1. Preparation of dithiooxamide functionalised multi walled carbon nanotubes.

Procedure for removal of $\mathbf{H g}$ (II) ion. The effect of different parameters such as $\mathrm{pH}$, sorbent dosage, time and the mercury concentration on removal of mercury ions were studied. The $\mathrm{pH}$ effect was studied within the $\mathrm{pH}$ range of 4.0-9.0. In other hand the effect of the sorbent dosage was studied by different absorbent values between 20-100 mg. Also the effect of the time was studied by different times between 10-70 min. Moreover, the effect of mercury concentration was observed within the concentration range of $40-300 \mathrm{mg} / \mathrm{L}$. Conventional one factor- at-a-time method was used, and optimised amount of any parameter was used to next optimisation of other amounts.

Dithiooxamide functionalized multi walled carbon nanotubes $(70 \mathrm{mg}$ ) was added to $100 \mathrm{~mL}$ of mercury(II) ions solution $(150 \mathrm{mg} / \mathrm{L})$. The $\mathrm{pH}$ value was adjusted 
by adding $0.5 \mathrm{~mL}$ of ammonia/ammonium chloride buffer solution $\left(1.0 \times 10^{-3} \mathrm{~mol} / \mathrm{L}, \mathrm{pH} 9.0\right)$. Afterwards, the solution was stirred at room temperature for $30 \mathrm{~min}$ and then the MWCNT sorbent separated from the solution using centrifuge for $5 \mathrm{~min}$ at $4000 \mathrm{rpm}$. For determination of residual mercury(II) ions, the supernatant was analysed by flame atomic absorption spectrometer (FAAS). Our calculation for mercury removal and loading amount has been done based on eq. 1 and eq. 2 .

$$
\mathrm{R} \%=\mathrm{C}_{\mathrm{i}}-\mathrm{C}_{\mathrm{e}} / \mathrm{C}_{\mathrm{i}} \times 100
$$

where:

$\mathrm{R} \%=$ mercury removal percent; $\mathrm{C}_{\mathrm{i}}$ and $\mathrm{C}_{\mathrm{e}}(\mathrm{mg} / \mathrm{L})=$ the initial and equilibrium concentrations of $\mathrm{Hg}(\mathrm{II})$, respectively.

$$
\text { L.A. }=\mathrm{V} \times \mathrm{C} \times \% \mathrm{R} / \mathrm{M}_{\mathrm{Hg}} \times \mathrm{m}_{\mathrm{s}}
$$

where:

L.A. = loading amount; $\mathrm{V}=$ volume of solution sample (L); $\mathrm{C}=$ concentration of $\mathrm{Hg}(\mathrm{mg} / \mathrm{L}) ; \mathrm{M}_{\mathrm{Hg}}=$ the atomic weight of $\mathrm{Hg}(\mathrm{g})$ and $\mathrm{m}_{\mathrm{s}}=$ the mass of nanosorbent $(\mathrm{g})$.

\section{Results and Discussion}

Synthesis of dithiooxamide functionalized MWCNT as sorbent. In order to verify the linkage between MWCNT and the dithiooxamide ligand, the Fourier transmission infrared spectroscopy (FT-IR) was used (Fig. 1a-b). Comparison of the FT-IR spectra of MWCNT$\mathrm{COOH}$ with that of MWCNT-dithiooxamide, gives important results to identify the groups substitution. The FT-IR spectra of MWCNT-COOH (Fig. 1a) identified the peaks of $\mathrm{C}=\mathrm{O}$ at $1704.96 \mathrm{~cm}^{-1}$ and $\mathrm{O}-\mathrm{H}$ at $3386.77 \mathrm{~cm}^{-1}$, respectively. In the FT-IR spectra of MWCNT-dithiooxamide (Fig. 1b), the sharp peak of $\mathrm{N}-\mathrm{H}$ bond appeared at the area of $3425.34 \mathrm{~cm}^{-1}$ instead of wide peak of $\mathrm{O}-\mathrm{H}$ group which proves attachment of dithiooxamide to the carbon nanotubes (see Scheme 1).

Surface morphology. The size and morphology of dithiooxamide functionalized MWCNT before and after absorbing the mercury(II) ions are illustrated in (Fig. 2a-b) by using SEM. After precipitating with mercury ions, Fig. $2 b$ indicates a significant change which was observed along the tube walls. This significant change on the surface of CNT proves the precipitation of mercury ions on this sorbent.

Optimisation of adsorption conditions. Effect of $p H$. The $\mathrm{pH}$ value of the solution is one of the most important

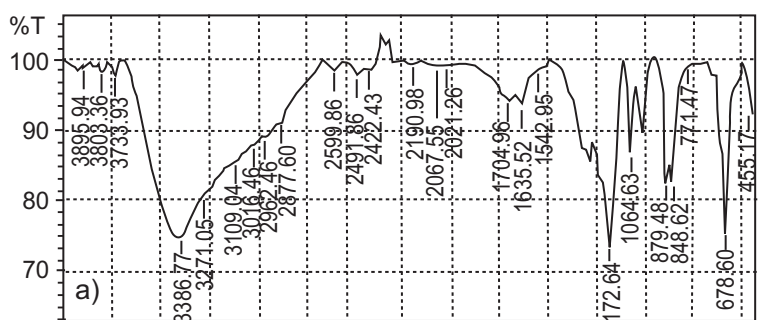

4000375035003250300027502500225020001750150012501000750500

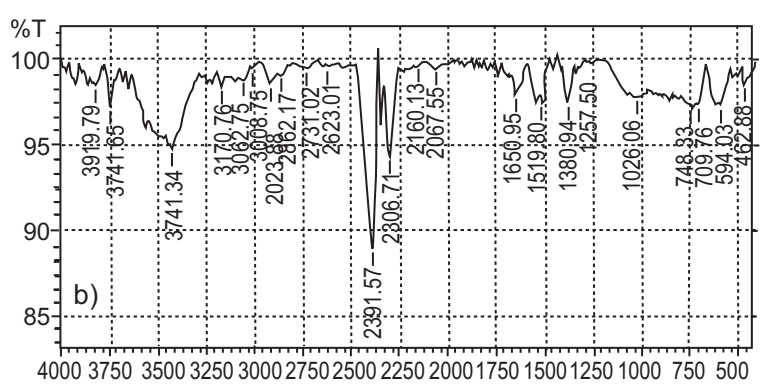

Fig. (1a-b). FT-IR spectrum of (a) MWCNT-COOH and (b) MWCNT-CO-dithiooxamide.
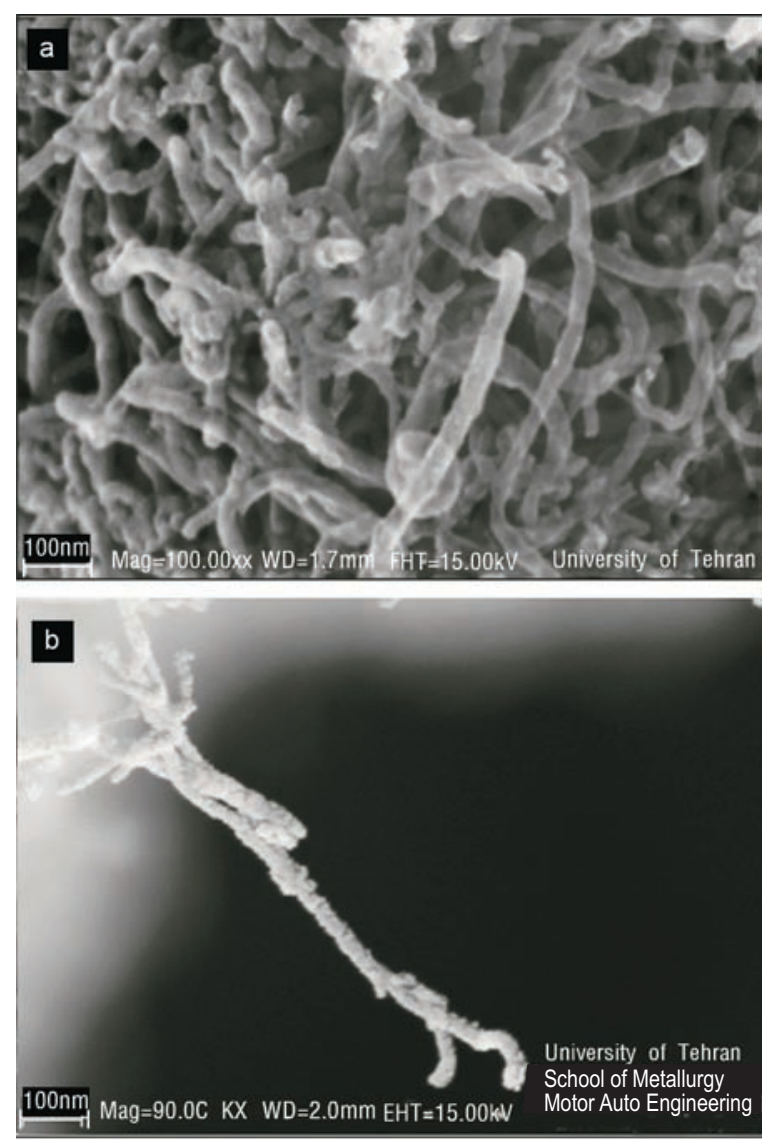

Fig. 2(a-b). SEM image of dithiooxamide multi walled carbon nanotubes (a) before absorption of mercury (II) ions, (b) after absorption of mercury(II) ions. 
factors which affect the adsorption behaviour of mercury ions on sorbents. It is not only due to the surface structure of sorbents, but it may also influence the interaction between sorbents and mercury ions. In this case, due to the presence of amide functional group in the ligand structure, the decrease in $\mathrm{pH}$ can also significantly reduce the activity of sorbent (Scheme 2). The effect of $\mathrm{pH}$ was studied within the $\mathrm{pH}$ range of 4.0-9.0. At low $\mathrm{pH}$ values the surface of dithiooxamide gives positive charge because of acidic situation. So repeal interaction will occur between the positive surface and $\mathrm{Hg}^{2+}$ resulting decrease in adsorption. In contrast at higher $\mathrm{pH}$ values, reveres interaction happens resulting increase in adsorption. According to Fig. 3, the most suitable $\mathrm{pH}$ value for this sorbent was found to be 9.0 which results in the highest amount of mercury removal.

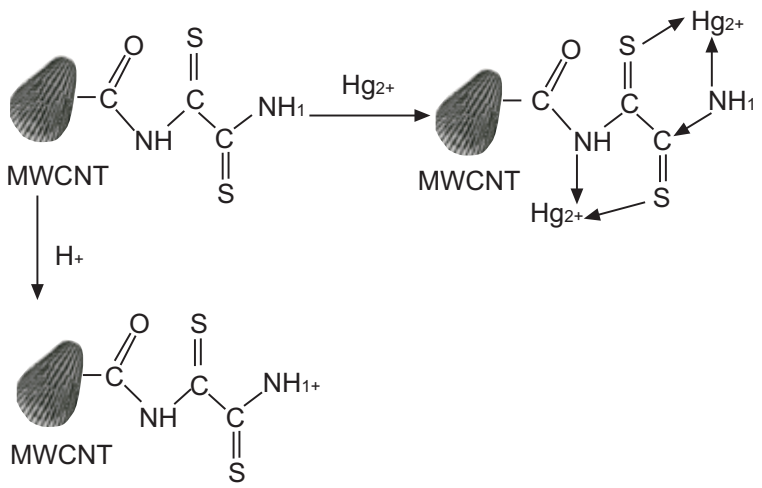

Scheme 2. Suggested binding model of dithiooxamide functionalised multi walled carbon nanotubes and mercury(II) ions.

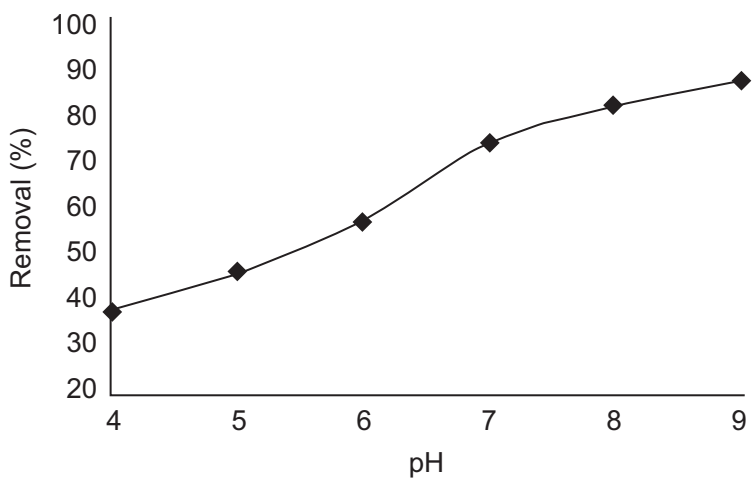

Fig. 3. The effect of $\mathrm{pH}$ on the sorbent activity. Removal conditions: aqueous solution volume (100.0 mL); sorbent dosage $(70 \mathrm{mg})$; time of adsorption (30 $\mathrm{min})$; concentration of mercury $(150 \mathrm{mg} / \mathrm{L})$.
Effect of the sorbent dosage. The effect of the sorbent dosage on the adsorption of $\mathrm{Hg}$ (II) was studied by different absorbent values between 20-100 mg. The results in Fig. 4 show that, $\mathrm{Hg}$ (II) was approximately, adsorbed on the surface of sorbent. According to these results, after about $70 \mathrm{mg}$ of sorbent, the value of adsorption for $\mathrm{Hg}$ (II) does not change significantly. So, $70 \mathrm{mg}$ of the sorbent was selected for further studies.

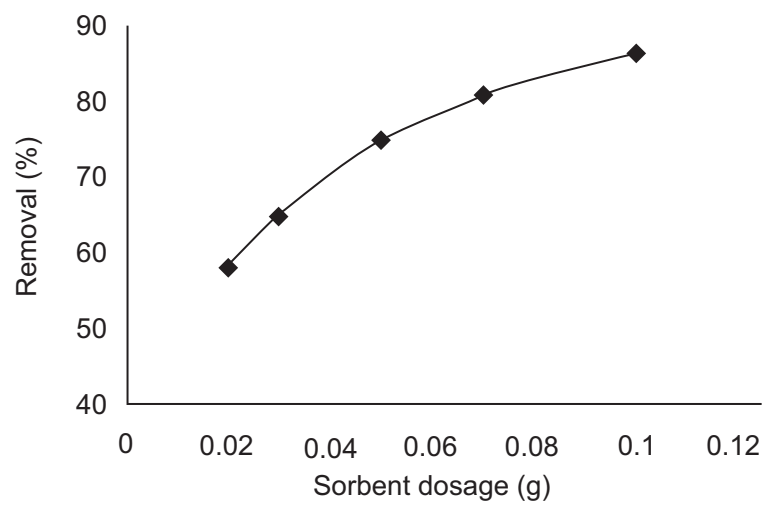

Fig. 4. The effect of sorbent dosage on adsorption. Removal conditions: aqueous solution volume (100.0 mL); $\mathrm{pH}(9.0)$; time of adsorption (30 $\mathrm{min})$; concentration of mercury $(150 \mathrm{mg} / \mathrm{L})$.

Effect of time. The effect of time on the adsorption of $\mathrm{Hg}$ (II) was studied by different times between 10-70 min and illustrated in Fig. 5. The results show that, after about $30 \mathrm{~min}$ of adsorption process, the value of adsorption does not change significantly. So, this time is the contact time required for achieving the adsorption equilibrium which is lower than the required contact time (120 min) (Johari et al., 2014).

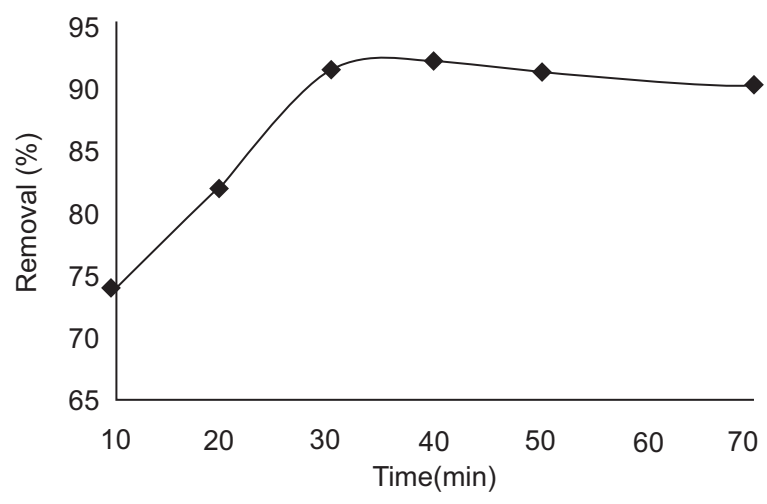

Fig. 5. The effect of time of adsorption. Removal conditions: aqueous solution volume $(100.0 \mathrm{~mL})$; sorbent dosage $(70 \mathrm{mg}) ; \mathrm{pH}$ (9.0); concentration of mercury $(150 \mathrm{mg} / \mathrm{L})$. 
Effect of $\mathbf{H g}(\boldsymbol{I I})$ concentration. To study the possibility of our proposed sorbent toward different concentrations of $\mathrm{Hg}(\mathrm{II})$, the effect of different concentrations of this cation was studied within the range of $40-300 \mathrm{mg} / \mathrm{L}$. There was a high value of adsorption at the low concentration of mercury ions. But when the ions dosage increased to $200 \mathrm{mg} / \mathrm{L}$, the activity of sorbent decreased. According to Fig. 6, the most appropriate concentration value for $\mathrm{Hg}$ (II) was found to be $150 \mathrm{mg} / \mathrm{L}$ based on the removal percent and also the loading amount for the applied sorbent is $1.02 \mathrm{mmol} / \mathrm{g}$ which is higher than as per the values of $0.720 \mathrm{mmol} / \mathrm{g}$ (Johari et al., 2014) and $0.351 \mathrm{mmol} / \mathrm{g}$ (Karthika and Sekar, 2012). Comparison of the presented method with other reported methods for removal of mercury show that presented method has better loading amount (Karthika and Sekar, 2012).

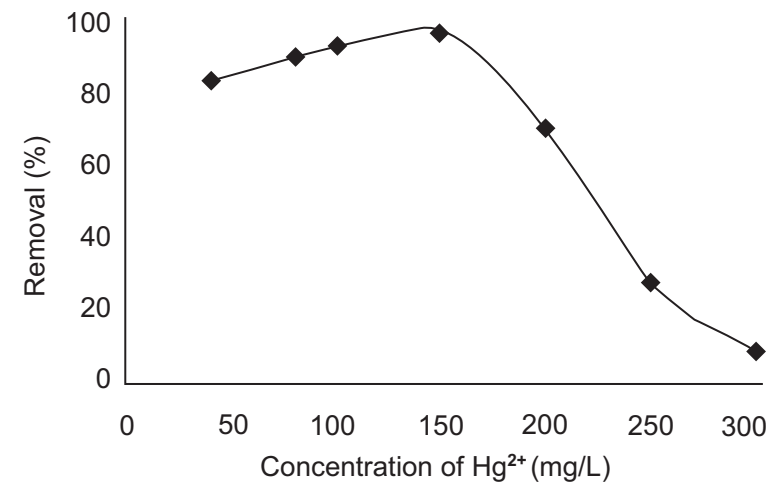

Fig. 6. The effect of mercury concentration on the sorbent activity. Removal conditions: aqueous solution volume $(100.0 \mathrm{~mL})$; time of adsorption (30 min); sorbent dosage $(70 \mathrm{mg}) ; \mathrm{pH}$ (9.0).

The amount of absorbed $\mathrm{Hg}$ (II) at the time of equilibrium based on the mass of sorbent was calculated using eq. 3 .

$$
\mathrm{q}_{\mathrm{e}}=\left(\mathrm{C}_{\mathrm{o}}-\mathrm{C}_{\mathrm{e}}\right) \times \mathrm{V} / \mathrm{W}
$$

where:

$$
\begin{aligned}
\mathrm{q}_{\mathrm{e}}= & \text { amount of absorbed } \mathrm{Hg}(\mathrm{II}) \text { at the time of } \\
& \text { equilibrium }(\mathrm{mg} / \mathrm{g}) ; \\
\mathrm{C}_{\mathrm{o}}= & \text { initial concentration of } \mathrm{Hg}(\mathrm{II})(\mathrm{mg} / \mathrm{L}) ; \\
\mathrm{C}_{\mathrm{e}}= & \text { residual concentration of } \mathrm{Hg}(\mathrm{II}) \text { in solution } \\
& (\mathrm{mg} / \mathrm{L}) \\
\mathrm{V}= & \text { volume of the solution }(\mathrm{L}) \text { and } \\
\mathrm{W}= & \text { mass of sorbent }(\mathrm{g}) .
\end{aligned}
$$

A scattered graph of $\mathrm{Hg}(\mathrm{II})$ removed amount, per gram of sorbent as a function of equilibrium $\mathrm{Hg}$ (II) concentration is given in Fig. 7. It can be seen that, at $\mathrm{Hg}$ (II) concentration of $150 \mathrm{mg} / \mathrm{L}$ maximum amount of $\mathrm{q}_{\mathrm{e}}$ is achieved which is totally in accordance to results of Fig. 6.

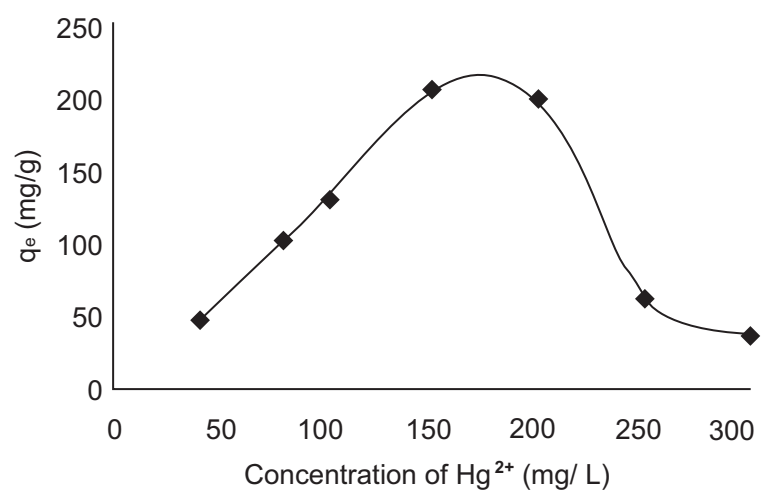

Fig. 7. A scattered graph of $\mathrm{Hg}(\mathrm{II})$ removed amount, per gram of sorbent as a function of equilibrium $\mathrm{Hg}$ (II) concentration. Removal conditions: aqueous solution volume $(100.0 \mathrm{~mL})$; time of adsorption (30 $\mathrm{min})$; sorbent dosage (70 mg); $\mathrm{pH}$ (9.0).

Effect of other ions. The effects of other familiar ions in aqueous samples on the removal of mercury were studied. In these experiments, $100.0 \mathrm{~mL}$ of solutions containing $150 \mathrm{mg} / \mathrm{L}$ of mercury and various amounts of interfering ions were treated according to the presented procedure. An ion was considered to interfere when its

Table 1. Effect of other ions on the removal of mercury

\begin{tabular}{lll}
\hline \hline Ion & Ion/Hg(II) (w/w) & Removal (\%) \\
\hline $\mathrm{Li}^{+}$ & 7 & 97.6 \\
$\mathrm{Na}^{+}$ & 7 & 96.1 \\
$\mathrm{Cu}^{2+}$ & 3 & 98.7 \\
$\mathrm{Ni}^{2+}$ & 2 & 95.5 \\
$\mathrm{Al}^{3+}$ & 2 & 97.3 \\
$\mathrm{Zn}^{2+}$ & 2 & 99.5 \\
$\mathrm{~Pb}^{2+}$ & 2 & 97.9 \\
$\mathrm{Cd}^{2+}$ & 2 & 97.2 \\
$\mathrm{Co}^{2+}$ & 3 & 99.1 \\
$\mathrm{Cr}^{3+}$ & 3 & 95.3 \\
$\mathrm{Fe}^{2+}$ & 2 & 99.3 \\
$\mathrm{NO}_{3}{ }^{-}$ & 7 & 98.6 \\
$\mathrm{Cl}^{-}$ & 5 & 96.7 \\
$\mathrm{SO}_{4}{ }^{2-}$ & 3 & 95.4 \\
\hline \hline
\end{tabular}


presence produced a variation of more than $5 \%$ in the removal of mercury in aqueous sample. The results of Table 1, indicate that the removal of mercury is almost quantitative in the presence of interfering ions.

\section{Conclusion}

A new effective sorbent was synthesised by functionalization of the MWCNT. Experiments show that the new modified MWCNT with a loading amount of $1.02 \mathrm{mmol} / \mathrm{g}$ is a powerful sorbent for removing the $\mathrm{Hg}$ (II) ions from water. This method indicates that 95.7\% removal of $\mathrm{Hg}^{2}+$ is possible at optimal conditions of $\mathrm{pH}=9$, mercury ion concentration $=150 \mathrm{mg} / \mathrm{L}$, and the sorbent dosage $=0.07 \mathrm{~g}$. The results showed that, MWCNT-dithiooxamide is an excellent absorbent for moderate concentrations of mercury ions. This proposed method applies an environment friendly non-toxic absorbent which does not threaten human health. Also this method is simple, highly sensitive, selective and relatively fast.

\section{Acknowledgement}

The authors thank the Research Council at the Qaemshahr Branch, Islamic Azad University for technical and financial support.

\section{References}

Barbara, C.F., Bonalume, G.W.L., Jesualdo Luiz, R. 2011. Functionalized carbon nanotubes for nanocomposites. In: $16^{\text {th }}$ International Conference on Composite Structures ICCS 16, A.J.M. Ferreira (ed), Porto, Portugal.

Boening, D.W. 2000. Ecological effects, transport, and fate of mercury: a general review. Chemosphere, 40: 1335-1351.

Chiarle, S., Ratto, M., Rovatti, M. 2000. Mercury removal from water by ion exchange resins absorption. Water Research, 34: 2971-2978.

El-Sheikh, A.H., Al-Degs, Y.S., Al-Asad, R.M., Sweileh, J.A. 2011. Effect of oxidation and geometrical dimensions of carbon nanotubes on $\mathrm{Hg}$ (II) sorption and preconcentration from real waters. Desalination, 270: 214-220.

Ghambarian, M., Khalili-Zanjani, M.R., Yamini, Y., Esrafili, A., Yazdanfar, N. 2010. Preconcentration and speciation of arsenic in water specimens by the combination of solidification of floating drop microextraction and electrothermal atomic absorption spectrometry. Talanta, 81: 197-201.
Green-Ruiz, C.R. 2006. Mercury(II) removal from aqueous solutions by nonviable Bacillus sp. from a tropical estuary. Bioresource Technology, 97: 1907-1911.

Hu, H., Ni, Y., Montana, V., Haddon, R.C., Parpura, V. 2004. Chemically functionalized carbon nanotubes as substrates for neuronal growth. Nano Letter, 4: 507-511.

Johari, K., Saman, N., Song, S.T., Heng, J.Y.Y., Mat, H. 2014. Study of $\mathrm{Hg}$ (II) removal from aqueous solution using lignocellulosic coconut fiber biosorbents: Equilibrium and kinetic evaluation. Chemical Engineering Communications, 201: 1198-1220.

Jones, A.P., Hoffmann, J.W., Smith, D.N., Feeley, T.J.3 ${ }^{\text {rd }}$, Murphy, J.T. 2007. DOE/NETL's phase II mercury control technology field testing program. Preliminary economic analysis of activated carbon injection. Environmental Science and Technology, 41: 1365 1371.

Kalita, G., Adhikari, S., Aryal, H.R., Ghimre, D.C., Afre, R., Soga, T., Sharon, M., Umeno, M. 2008. Flourination of multi-walled carbon nanotubes (MWNTs) via surface microwave (SW-MW) plasma treatment. Physica E, 41: 299-303.

Karthika, C., Sekar, M. 2012. Removal of Hg(II) ions from aqueous solution by acid acrylic resin-A study through absorption isotherms analysis. I Research Journal of Environment Sciences, 1: 34-41.

Klasson, K.T., Lima, I.M., Boihem, J.L.L., Wartelle, L.H. 2010. Feasibility of mercury removal from simulated flue gas by activated chars made from poultry manures. Journal of Environmental Management, 91: 2466-2470.

Liu, S.H., Yan, N.Q., Liu, Z.R., Qu, Z., Wang, H.P., Chang, S.G., Miller, C. 2007. Using bromine gas to enhance mercury removal from flue gas of coalfired power plants. Environmental Science and Technology, 41: 1405-1412.

Malic, E., Maultzsch, J., Reich, S., Knorr, A. 2010. Excitonic absorption spectra of metallic singlewalled carbon nanotubes. Physical Review B, 82: 035433.

Manohar, D.M., Krishnan, A.K., Anirudhan, T.S. 2002. Removal of mercury(II) from aqueous solutions and chlor-alkali industry wastewater using 2mercaptobenzimidazole-clay. Water Research, 36: 1609-1619.

Mishra, S., Tripathi, R.M., Bhalke, S., Shukla, V.K., Puranik, V.D. 2005. Determination of methylmercury and mercury(II) in a marine ecosystem using solid- 
phase microextraction gas chromatography-mass spectrometry. Analytica Chimica Acta, 551: 192198.

Pourreza, N., Parham, H., Kiasat, A.R., Ghanemi, K., Abdollahi, N. 2009. Solid phase extraction of mercury on sulfur loaded with N-(2-chloro benzoyl)N'-phenylthiourea as a new adsorbent and determination by cold vapor atomic absorption spectrometry. Talanta, 78: 1293-1297.

Sone, K., Yagi, M. 2009. Chemical adsorption onto an ITO substrate of single-wall carbon nanotube functionalized by carboxylic groups as an efficient support for electrocatalyst. Electroanalysis, 21: 144-149.

Sukocheva, O.A., Yang, Y., Gierthy, J.F., Seegal, R.F. 2005. Methyl mercury influences growth-related signaling in MCF-7 breast cancer cells. Environmental Toxicology, 20: 32-44.

Tahermansouri, H., Aryanfar, Y., Biazar, E. 2013. Synthesis, characterization, and the influence of functionalized multi-walled carbon nanotubes with creatinine and 2-aminobenzophenone on the gastric cancer cells. Bulletin of Korean Chemical Society, 34: 149-153.

Teixeira Tarley, C.R., Barbosa, A.F., Segatelli, M.G., Figueiredo, E.C., Luccas, P.O. 2006. Highly improved sensitivity of TS-FF-AAS for Cd(II) determination at $\mathrm{n} \mathrm{L} \mathrm{L}^{-1}$ levels using a simple flow injection minicolumn preconcentration system with multiwall carbon nanotubes. Journal of Analytical Atomic Spectrometry, 21: 1305-1313.
Venkatesan, N., Yoshimitso, J., Ito, Y., Shibata, N., Takada, K. 2005. Liquid filled nanoparticles as a drug delivery tool for protein therapeutics. Journal Biomaterials, 26: 7154-7163.

Wang, X., Li, W., Chen, Z., Waje, M., Yan, Y. 2006. Durability investigation of carbon nanotube as catalyst support for proton exchange membrane fuel cell. Journal of Power Sources, 158: 154-159.

Wu, G., Wang, Z., Wang, J., He, C. 2007. Hierarchically imprinted organic-inorganic hybrid sorbent for selective separation of mercury ion from aqueous solution. Analytica Chimica Acta, 582: 304-310.

Yang, K., Gu, M., Guo, Y., Pan, X., Mu, G. 2009. Effects of carbon nanotubes functionalization on the mechanical and thermal properties of expoxy composites. Carbon, 47: 1723-1737.

Yu, J.G., Huang, K.L., Liu, S.Q., Tang, J.C. 2008a. Preparation and characterization of soluble methyl- $\beta$-cyclodextrin functionalized single-walled carbon nanotubes. Physica E: Low-Dimensional Systems \& Nanostructures, 40: 689-692.

Yu, J.G., Huang, K.L., Tang, J.C. 2008b. Chemical attachment of dibromocarbene to carbon nanotubes. Physica E: Low-Dimensional Systems \& Nanostructures, 41: 181-184.

Zong, G., Chen, H., Qu, R., Wang, C., Ji, N. 2011. Synthesis of polyacrylonitrile-grafted cross-linked $\mathrm{N}$-chlorosulfonamidated polystyrene via surfaceinitiated ARGET ATRP, and use of the resin in mercury removal after modification. Journal of Hazardous Materials, 186: 614-621. 